\title{
Facing Socio-Cultural Changes through Lifelong Learning Based on Real-Life Problems
}

\author{
M. I. Suhifatullah \\ Non Formal Education Department, University of Ibn Khaldun Bogor \\ fkipuikabogor@gmail.com
}

\begin{abstract}
Life in its various aspects never walked anywhere, but continues to change either by means of a revolutionary or evolutionary. Well it was done intentionally planned or occurred naturally. Nevertheless, the impact of a change is not always positive, none of them have highly negative impact on quality of life. To get the positive benefits of a change, the necessary adaptability wisely and intelligently based on the core moral values, knowledge and skills are growing. Related to this, the process of lifelong learning is the only way to acquire the ability to adapt in the face of socio-cultural changes that continue throughout life. This means there needs to be an effort to develop a culture of lifelong learning in the community. The method of writing scientific work is done through the study of literature, the results of which can describe the urgency of a lifelong learning process in the face of socio-cultural changes. The implication of this paper is expected to encourage people to become more adaptive to socio-cultural changes through lifelong learning so as to improve the quality of life.
\end{abstract}

Keywords-Changes, lifelong learning based the real-life problems

\section{INTRODUCTION}

Like it or not, life will continue to change in various aspects and dimensions, which takes place either naturally or because of a deliberate policy by a local, national and global. In order to survive, or to come out as a winner, then there is no other choice but to seek to develop the best the ability to adapt to various changes. Expressed by Charles Darwin quoted by Rhenald Kasali that: "not the strongest that are able to live long, but adaptive, is those who have always lived adapt to changes." [1] Also disclosed by Muhammad Iqbal in his poem: "Stop, there is no place on the road this. Attitude means slow death. They are engaged, they are going forth. Those who wait, even for a moment must have been run over. "[2]

Characteristics that distinguish between developed societies with people who have not developed, among others, in terms of the ability to adapt to the changes that continue to occur throughout life in its various aspects. In advanced societies they tend to be more anticipatory and actively understand the changes through a lifelong learning process that creatively trying to solve problems that occur in real life. There are many facts that academic knowledge is often helpless in dealing with complex real-life problems. They are learning from real-life problems it is often better able to cope and adapt to change.

The process of lifelong learning in its various forms should be developed through experiential learning so that students have the ability to solve problems that occur in real life. Experiential learning is any learning that supports students in applying Reviews their knowledge and conceptual understanding to real-world problems or situations where the instructor directs and facilitates learning. The classroom, laboratory, or studio can serve as a setting for experiential learning through activities such as embedded and problembased case studies, guided inquiry, simulations, experiments, or art projects. [3] Experiential learning provides the conditions for optimally supporting student learning. When students are engaged in learning experiences that they see the relevance of; they have increased motivation to learn. Also students are motivated when they are provided opportunities for practice and feedback. Experiential learning meets reviews these criteria. [4]

\section{METHODS}

This research includes the study of research literature to find references relevant theory to the case or the problems found. References theory obtained by the research literature studies serve as the basic foundation and a major tool for research practice in the middle of the field.

\section{RESULTS AND DISCUSSION}

The hallmark of a life is change, it can even be said that change is the only feature that is inherent in life. Changes include various aspects of life, not only in the use of technologies, methods, and new systems, but also changing the way of thinking and behaving. So, nothing is eternal in this world, except for the change. Starting from the small things to the big things concerning the livelihood of the people will always change. So, to say that the change is eternal.

The 21st century is an era of global change very fast and challenging, it is as a result of the rapid development of science and technology. Robert B. Tucker quoted by Bandono, to identify their top ten challenges in the 21st century, namely: 1). Speed, 2). Convenience, 3). Age Wave, 4). Choice, 5). Life style, 6). Discounting, 7). Value added, 8). Customer Service, 9). Techno age, 10). Quality control. [5]

Within the scope of the ASEAN countries, Indonesia has entered a major change, especially in the economic life is regulated through a global policy with the name of the ASEAN Economic Community (AEC). AEC is a form of economic integration of ASEAN which means the entry into force of the free trade system among the ASEAN countries. Indonesia and 
nine other ASEAN member countries have agreed agreement ASEAN Economic Community (AEC). The existence of these policies will encourage changes in economic behavior ASEAN community, especially in the trading of goods and services. This change on the one hand will open up great opportunities for businesses of goods and services, but on the other hand it leads to competition or the increasingly sharp competition among countries in Southeast Asia.

In welcoming the changes, there is no other choice but to be able to adapt to change, if you do not want to be a nation crushed by the changes. In the past, hard work and loyal service led to a secure future. Today, employers and third-party payers place a premium on Reviews those who continually acquire skills and knowledge and who have the resilience and flexibility to adjust to the evolving needs of the global labor market. Thus, the ability to engage in lifelong self-directed learning is the single most important competence that people must possess. [6]

On the basis of that statement, the behavior of lifelong learning need to be grown in Indonesian society in order not to run over the changes at once can compete or compete in the global market of the ASEAN Economic Community.

Related to changes in the 21 st century. In late 1997, the Commission for a Nation of Lifelong Learners, made up of leaders in business, labor, education, government, and philanthropy, presented its recommendations in "A Nation Learning: Vision for the 21st Century" [7] The Commission defined lifelong learning as "a continuously supportive process which stimulates and empowers individuals...to acquire all the knowledge, values, skills and understanding they will require throughout their lifetimes... and to apply them with confidence, creativity, and enjoyment in all roles, circumstances, and environments." [8]

In all human life continues to change, both involving internal changes as well as changes in the environment he faces life. Internal changes that occur in humans as a result of the activity of interaction with the environment are also constantly changing. Human interaction with their environment which then gives the experience in the form of behavioral changes, according to the theory of behavior is called the learning process. This means that people will have difficulty in adapting to changes in the environment of life, when stopping or less active in the learning process. Therefore, human beings have to simultaneously perform activities of lifelong learning in order to adapt to changes, and able to compete in a market that continues to change.

Lifelong learning is a concept that puts the learning activities as activities of daily life in an attempt to answer the curiosity, curiosity can do something, and a sense of want to change certain attitudes related to the problems encountered in life as a result of continual change. This confirms that the learning process should not be stopped after a person completes all levels of formal education at school or college. In fact it can be said, one may drop out of school but should never give up learning.

This definition emphasizes lifelong learning as (a) continuous (it never stops); (b) supportive (it isn't done alone); (c) stimulating and empowering (it's self-directed and active, not passive); (d) incorporating knowledge, values, skills, and understanding (it's more than what we know); (e) spanning a lifetime (it happens from our first breath to our last); (f) applied (it's not just for knowledge's sake); (g) incorporating confidence, creativity, and enjoyment (it's a positive, fulfilling experience); and (h) inclusive of all roles, circumstances, and environments (it applies not only to our chosen profession, but to our entire life) [9]

Someone must never stop learning, because throughout his life continues to deal with problems that tend to differ along with the continued occurrence of changes, both in the micro and macro scale. However, not all the learning needs of people in various spheres of life can be fulfilled by a formal educational institution or school. This means the process of lifelong learning through non-formal education, informal and independent learning directly from real life, as a very important activity for everyone. In fact it can be said that learning in a real sense is something that lasts throughout a person's life. Based on the concept, then lifelong learning is sometimes said to be a continuous learning. Through a lifelong learning process, someone can renew the knowledge, skills and attitudes needed in the framework of adjustment to change, so it does not fall behind the times and still can contribute to life on the environment.

Lifelong learning has emerged as one of the major challenges for the worldwide knowledge society of the future. A variety of events support this claim: (a) 1996 was the "European Year of Lifelong Learning"; (b) the United Nations Educational, Scientific and Cultural Organization (UNESCO) included "Lifetime Education" as one of the key issues in its planning; and (c) the G7-G8 group of countries named "Lifelong Learning" as a main strategy in the fight against unemployment. [10]

Education is not a preparation of life. It is life itself. This is the opinion of experts of education John Dewey, an education expert from the United States. Therefore, he believes that the education unit, called the school are viewed as a social institution. Thus, for John Dewey, the education process is actually rather a social process, a learning process in life and living. Once again, John Dewey declared that education is a process of living and not a preparation for future living. [11]

John Dewey's statement can be interpreted, that the learning activities should be integrated in the social process that continues throughout life. Therefore everyone should have the initiative to conduct independent learning throughout life, so it has the ability to solve real-life problems that continues to change. Hammond and Collins [12] describe self-directed learning as "a process in which learners take the initiative, with the support and collaboration of others; for increasing self- and social awareness; critically analyzing and reflecting on their situations; diagnosing their learning needs with specific reference to competencies they have helped identify; formulating socially and personally relevant learning goals; identifying human and material resources for learning; choosing and implementing appropriate learning strategies; and reflecting on and evaluating their learning." This humanistic characterization of self-directed learning implies a sense of 
social awareness and responsibility, self-actualization, and the acceptance of personal responsibility for one's own learning. [13]

Education is prepared for the future tends to be academic and often did not touch the issue in real life at hand. The future life is often not accurately being anticipated as a reference in formulating the formal education curriculum. Even curriculum has been formulated for the future, are often left behind by the changes. Therefore, learning in the context of lifelong learning is the activity of solving real-life problems through creative learning process. The challenge for lifelong learning is to fundamentally rethink learning, teaching, and education for the information age in an attempt to change mind-sets. Lifelong learning involves and engages learners of all ages in acquiring and applying knowledge and skills in the context of authentic, self-directed problems. [10] Lifelong learning process can be described as follows:

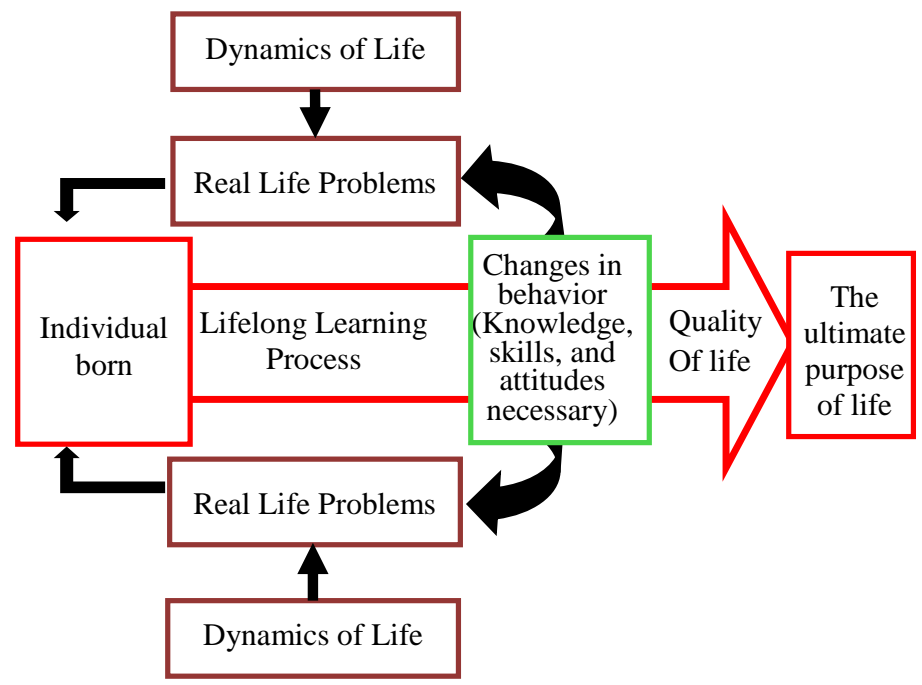

Fig. 1. The process of Lifelong Learning

Figure 1, can be interpreted, that lifelong learning is a learning activity that began since the individual was born and continues to continue doing so as to obtain a change of behavior in the form of knowledge, skills and attitudes needed to solve real-life problems as a result of the dynamics of life that continues to change throughout life. Lifelong learning through individual can continue to improve the quality of life until the end of his life.

\section{CONCLUSIONS}

The dynamics of life is always produced many good changes which occur naturally or are planned. Changes continue throughout life and always create the problem or disequilibrium and threaten the reliability especially that has not been established. There is only one way in the face of change that continues over time, through a lifelong learning process based on real-life problems.

The process of lifelong learning should be a good society movement is done by individually or collectively or in conjunction with the build centers of community service learning activities in each Rukun Warga (RW). This can be done if there is a strong initiative from the authorities through cooperation with universities or other institutions that can provide a source of learning, for example Studio Learning Activities or individual learning resources from volunteers who can serve the learning needs of the community. Through the centers of community learning were highlighted by the competent authorities, is expected to be a forum for people to acquire knowledge and skills in order to solve real-life problems

To support the movement of people in lifelong learning, it is necessary to have assistants who are appointed by the authorities either as honorary or fixed to administer the programs of non-formal education in each village. It is highly likely if the existence of village funds can also be used to improve the quality of rural human resources able to compete in the face of the global market, through the centers of community learning.

\section{REFERENCES}

[1] Kasali, Rhenald, Change, Jakarta: PT. Gramedia Pustaka Utama, 2007

[2] Iqbal, Muhammad, The Reconstruction of Religious Thought In Islam, Jakarta: Tintamas, 1966

[3] Wurdinger, D. D., \& Carlson, J. A. Teaching for experiential learning: Five approaches that work. Lanham, MD: Rowman \& Littlefield Education. 2010.

[4] Ambrose, S. A., Bridges, M. W., DiPietro, M., Lovett, M. C., \& Norman, M. K. How learning works: 7 research-based principles for smart teaching. San Francisco, CA: Jossey- Bass. 2010

[5] Bandono, Tantangan Perguruan Tinggi dalam Era Global. Orasi Ilmiah dalam rangka Dies Natalis ke 45 dan Wisuda Sarjana Universitas PGRI Yogyakarta, Universitas PGRI Yogyakarta, 2007

[6] Knowles,MS. Learning to learn across the life span. San Francisco, Calif: Jossey-Bass, 1990.

[7] Commission for a Nation of Lifelong Learning. A nation learning: vision for the 21st century. Washington, DC: Commission for a Nation of Lifelong Learning, 1997.

[8] Jannette Collins, Lifelong Learning in the 21st Century and Beyond, From the Department of Radiology, University of Wisconsin Hospital and Clinics, E3/311 Clinical Science Center, 600 Highland Ave, Madison, WI 53792-3252. Received July 10, 2008

[9] DuyffRL. The value of lifelong learning: key element in professional career development. J Am Diet Assoc1999; 99(5): 538-543. CrossRef, Medline

[10] FischerG. Lifelong learning and its support with new media: cultural concerns. In: Smelser NJ, Baltes PB, eds. International encyclopedia of the social \& behavioral sciences. Oxford, England: Elsevier, 2001.

[11] http://suparlan.com/4/pendidikan-sepanjang-hayat

[12] Hammond,M, Collins R. SDL: critical practice. New York, NY: Nichols/GP Publishing, 1991.

[13] SchweinfurthJM. Lifelong learning in otolaryngology: self-directed learning. Otolaryngol Clin North Am2007; 40(6): 1323-1330. CrossRef, Medline 